\title{
The effect of cortisone acetate on the course of development of experimental protein-energy malnutrition in rats
}

\author{
By P. G. LUNN, R. G. WHITEHEAD, B. A. BAKER \\ AND S. AUSTIN \\ University of Cambridge and Medical Research Council, Dunn Nutrition Unit, \\ Milton Road, Cambridge $\mathrm{CB}_{4} \times \mathrm{X \mathcal {J }}$
}

(Received 6 March I976-Accepted I8 May 1976)

\begin{abstract}
I. The role of corticosteroids in determining which clinical features of protein-energy malnutrition develop on a deficient diet has been studied by the administration of cortisone acetate to experimentally malnourished rats fed $a d l i b$. on a mixture containing $31 \mathrm{~g}$ protein $/ \mathrm{kg}$.

2. Daily administration of $1 \cdot 25 \mathrm{mg}$ cortisone acetate did not affect dietary intake, which remained the same as in saline $(9 \mathrm{~g}$ sodium chloride $/ \mathrm{l})$-injected controls. Plasma albumin concentrations, however, increased from a low value of $25.7 \mathrm{~g} / 1$ to $47.2 \mathrm{~g} / \mathrm{l}$ and this was accompanied by an increase both in liver weight and protein content. On the other hand, the protein content of muscle decreased.

3. These changes in the protein contents of liver and muscle were associated with alterations in the corresponding free amino acid pools. The free amino acid content of muscle generally decreased, but in liver many amino acids were increased.
\end{abstract}

The classical explanation for the difference between kwashiorkor and marasmus is that the former is produced by a diet low in protein but adequate in energy, whilst marasmus is the result of an over-all dietary deficiency. However, why some malnourished children become marasmic and others on apparently the same diet develop kwashiorkor is still an unsolved question, but it is known that different changes in endocrine activity occur during the development of the two forms of protein-energy malnutrition (Waterlow \& Alleyne, I97x; Whitehead \& Alleyne, 1972; Lunn, Whitehead, Hay \& Baker, 1973; Rao, 1974).

It is generally agreed that plasma cortisol concentrations are increased in all types of severe protein-energy malnutrition (Abbassy, Mikhail, Zeitoun \& Ragab, 1967; Alleyne \& Young, I967; Lunn et al. I973; Rao, 1974). However, Lunn et al. (1973) found that plasma cortisol concentration in children with kwashiorkor was related to the extent of wasting; the more wasted the children, the higher was the plasma cortisol concentration. Children with marasmus invariably have cortisol concentrations higher than those of children with kwashiorkor (Abbassy et al. 1967; Lunn et al. 1973; Lunn, Whitehead, Baker \& Austin, unpublished results). Moreover, it has been found that stimulation of the adrenals with adrenocorticotrophic hormone or one of its analogues produces greater increases in plasma cortisol in children with marasmus than in those with kwashiorkor (Rao, Srikantia \& Gopalan, I968; Rao, I974).

Such evidence has led to the suggestion that the difference between the two syndromes might lie in the response of the adrenals. If plasma cortisol concentrations are consistently higher during the period when children are being subjected to proteinenergy malnutrition, it is the marasmic form which eventually presents; if cortisol 
concentrations remain low during the preclinical phase, kwashiorkor is the more likely.

The purpose of this experiment was to test this hypothesis by determining whether cortisone acetate administration to rats fed on a low-protein diet could reverse the development of hypoalbuminaemia. Changes in the distribution of amino acids between muscle and liver in response to this hormone have also been studied.

\section{EXPERIMENTAL}

\section{Animals}

Eighty males from a specific pathogen-free strain of hooded rats were used in the experiment. The animals were weaned at 3 weeks onto a synthetic diet containing $210 \mathrm{~g} / \mathrm{kg}$ for I week, after which ten of the animals were killed. Those remaining were changed to a diet containing $3 \mathrm{I} \mathrm{g} / \mathrm{kg}$, on which they were maintained throughout the remainder of the experiment. After a further $6 \mathrm{~d}$, ten more animals were killed (day o), and those left were divided into two groups. One group was given daily subcutaneous injections of $\times \cdot 25 \mathrm{mg}$ cortisone acetate (Roussel Lab. Ltd, London) for periods up to $15 \mathrm{~d}$, and the other group saline ( $9 \mathrm{~g}$ sodium chloride/1) in a similar manner. Food intake measurements were carried out every day on each rat. Full details of the diet have been published previously (Lunn, Whitehead \& Baker, 1976).

Five animals from each group were killed on days $1,2,4,7$, 10 and $I_{5}$ from the start of the injections. Blood was collected by cardiac puncture from rats anaesthetized with Nembutal (Abbott Laboratories Ltd, Queensborough, Kent), into tubes containing potassium ethylenediaminetetraacetic acid. The liver and gastrocnemius muscle were removed and weighed and about $\mathrm{I} g$ of each (plus some quadriceps muscle to make up muscle weight) was added to $5 \mathrm{ml}$ trichloroacetic acid solution ( $100 \mathrm{~g} / \mathrm{l})$ (TCA). The tissues were homogenized and the supernatant fraction removed after centrifugation. 'The tissue extracts, together with the plasma, were stored at $-20^{\circ}$ until analysed.

\section{Chemical analysis}

Free amino acids were determined using an AutoAnalyzer (Model TSM-I; Technicon Instruments Co. Ltd, Basingstoke, Hants) coupled to an automatic integrator (model CRS-2Io; Infotronics (UK) Ltd, Wantage, Oxon).

Plasma albumin was estimated by an automated dye-binding procedure using bromocresol green (Northam \& Widdowson, 1967). Plasma total protein was measured by an automated Biuret method (Technicon Instruments Co. Ltd, I967). Muscle and liver protein contents were measured in the TCA extracts before centrifugation, also using a Biuret method (Gornall, Bardawill \& David, r949).

Plasma insulin was measured by method $\mathrm{C}$ of Hales $\&$ Randle (1963), as supplied in kit form by the Radiochemical Centre, Amersham, Bucks.

Plasma corticosterone were assayed using protein-binding techniques based on the work of Murphey (1967). For both assays $200 \mu \mathrm{l}$ ethanol was added to $20 \mu \mathrm{l}$ plasma in a small plastic tube. The tube was shaken and then evaporated to dryness overnight in an incubator at $37^{\circ}$. Then, $1.0 \mathrm{ml}$ protein-binding reagent (see later) was added, 
Table $\mathrm{x}$. Food intakes of rats fed on a low-protein diet (3 $\mathrm{g}$ protein $/ \mathrm{kg}) *$ and given daily subcutaneous injections of either saline ( $9 \mathrm{~g}$ sodium chloride/l or $\mathrm{I} \cdot 25 \mathrm{mg}$ cortisone acetate

(Mean values with their standard errors for thirty animals/group for the period from the start of injections to when they were killed)

Treatment $\quad$.

Total food intake $(\mathrm{g} / \mathrm{d})$

Energy intake $(\mathrm{kJ} / \mathrm{d})$

Protein intake $(\mathrm{g} / \mathrm{d})$

Total food intake ( $\mathrm{g} / \mathrm{kg}$ body-wt per d)

Energy intake (MJ/kg body-wt per d)

Protein intake $(\mathrm{g} / \mathrm{kg}$ body-wt per $\mathrm{d})$

\begin{tabular}{cl}
\multicolumn{2}{c}{ Saline } \\
$\begin{array}{c}\text { Mean } \\
1816\end{array}$ & 0.3 \\
181 & 5 \\
0.35 & 0.01 \\
140 & 4 \\
2.14 & 0.06 \\
4.2 & 0.1
\end{tabular}

\begin{tabular}{cl} 
Mean & \multicolumn{1}{c}{ SE } \\
II.5 & 0.4 \\
180 & 6 \\
0.35 & 0.01 \\
I 48 & 4 \\
2.31 & 0.06 \\
4.4 & 0.1
\end{tabular}

Differences between saline- and cortisone acetate-treated animals were not significant by Student's $t$ test.

* For details, see Lunn, Whitehead \& Baker (1976).

and the tube incubated at $45^{\circ}$ for Io min, after which it was cooled to below $4^{\circ}$, and the following procedures were carried out. Bound and free corticosteroids were separated by the addition of $0.5 \mathrm{ml}$ dextran-coated carbon suspension; the tube contents were mixed, and after 10 min centrifuged; $0.5 \mathrm{ml}$ supernatant fraction was removed and the amount of radioactivity measured. Addition of the $\mathrm{C}$ suspension took less than 3 min between first and last tubes, consequently thirty-two tubes were run per batch, each batch consisting of six standards, a quality control serum and twenty-five unknowns.

The protein-binding reagent for the corticosterone estimation contained $50 \mu \mathrm{Ci}$ $\left[{ }^{3} \mathrm{H}\right]$ corticosterone, $3 \mathrm{ml}$ normal rat plasma, $20 \mathrm{ml}$ ethanol $/ 1$ phosphosaline buffer (0.05 M-phosphate buffer, $\mathrm{pH}_{7} \cdot 4,9 \mathrm{~g} \mathrm{NaCl} / 1$ ). For cortisone plus corticosterone estimations, $5 \circ \mu \mathrm{Ci}\left[{ }^{3} \mathrm{H}\right]$ cortisol, $10 \mathrm{ml}$ chicken plasma, $20 \mathrm{ml}$ ethanol $/ 1$ phosphosaline buffer.

The $\mathrm{C}$ suspension contained $65^{\circ} \mathrm{mg}$ dextran T-70 (Pharmacia Ltd, Uppsala, Sweden) $+6 \cdot 25$ g Norit A charcoal (Sigma Chemical Co., London)/1 phosphosaline buffer.

\section{RESULTS}

\section{Food intake}

Injection of cortisone acetate did not affect food consumption, whether expressed as total intake or relative to body-weight. Consequently both cortisone acetate- and saline-injected groups had the same energy and protein intakes (Table I).

\section{Weight changes}

Body-weight. Body-weight changes are shown in Fig. I $a$. Animals receiving cortisone acetate injections slowly lost weight throughout the experiment, while the salineinjected group remained at a constant weight.

Muscle weight. Gastrocnemius muscle was affected in a similar way (Fig. I $b$ ). The 

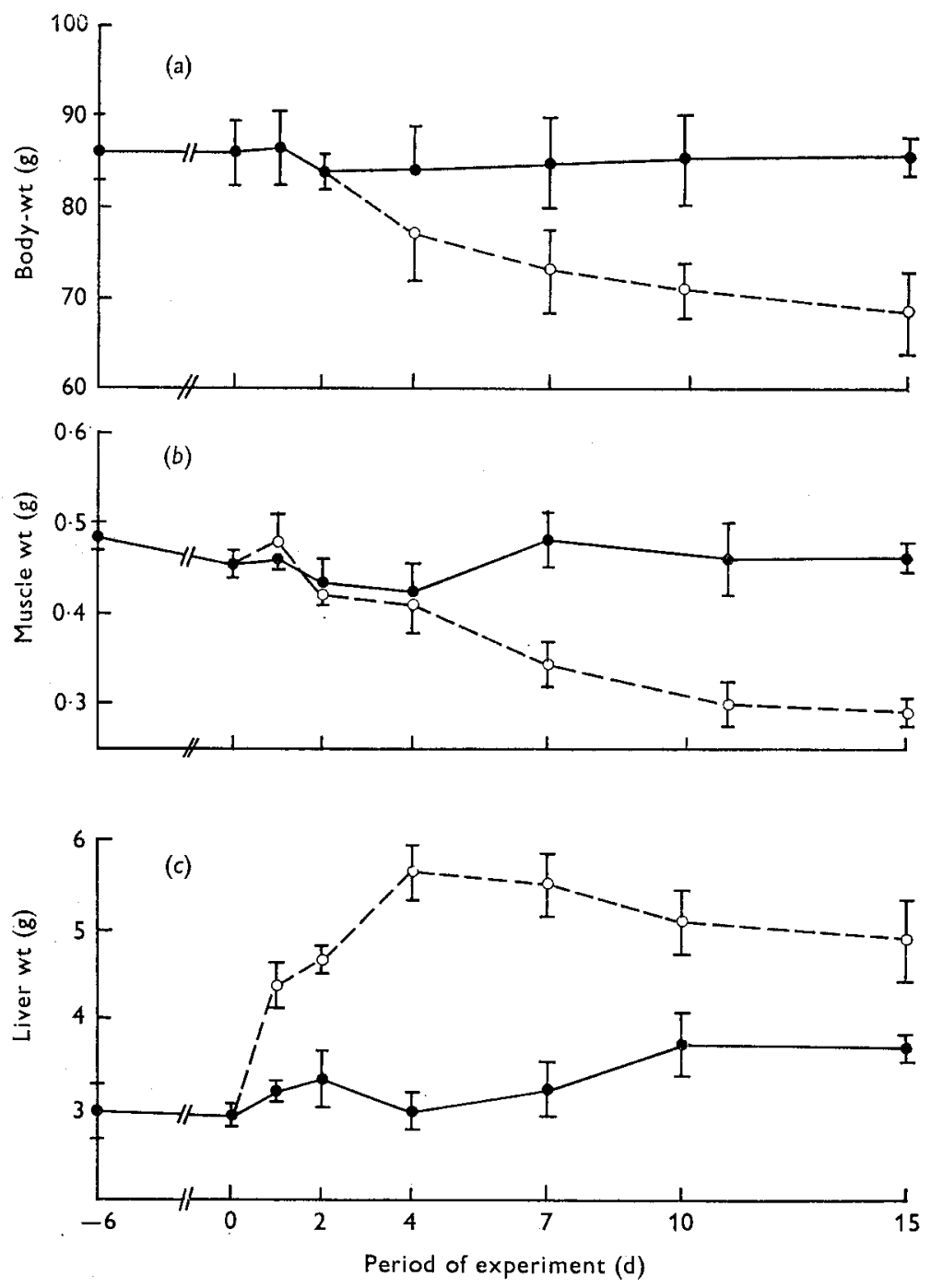

Fig. x. Changes (g) in (a) body-weight, (b) gastrocnemius muscle weight, (c) liver weight induced by daily subcutaneous injections of $1.25 \mathrm{mg}$ cortisone acetate to rats fed on a lowprotein diet (3 I g protein $/ \mathrm{kg}$ ) (for details of diet, see Lunn, Whitehead \& Baker ( 1976$)$ ). Mean values with their standard errors, represented by vertical bars, for five rats/group, except day 6 before the start of injections, and day 0 , when injections were started, when there were ten rats/ group. (-), Saline (9g sodium chloride/l)-injected; $(\bigcirc--\bigcirc)$, cortisone-injected. The decrease in body-weight was significant from day to onwards $(P<0.05)$, that of gastrocnemius muscle weight from day 7 onwards $(P<0.01)$. The liver weight was significantly increased from day I onwards. $(P<0.01)$.

percentage loss of weight, however, was much greater; for example, by day 15 cortisone-acetate treatment had only induced a decrease in body-weight, of approximately $19 \%$, but the gastrocnemius muscle weight was reduced by $35 \%$. Assuming that on day o muscle composed $45 \%$ of the total body-weight (Munro, I970), this loss of musculature would account for about $85 \%$ of the total body-weight loss recorded. 
Table 2. The effect of daily subcutaneous injections of either saline ( $9 \mathrm{~g}$ sodium chloride/l) or I.25 mg cortisone acetate on liver and muscle protein contents of rats fed on a lowprotein diet (3 $\mathrm{g}$ protein $/ \mathrm{kg}$ )

(Mean values with their standard errors for five animals/group, except on day 0 when values are for ten animals/group)

\begin{tabular}{|c|c|c|c|c|c|c|c|c|}
\hline \multirow{3}{*}{$\begin{array}{l}\text { Treatment } \\
\text { Period after } \\
\text { start of in- } \\
\text { jections (d) }\end{array}$} & \multicolumn{4}{|c|}{ Protein concentration (mg/g wet wt) } & \multicolumn{4}{|c|}{ Total liver protein (mg) } \\
\hline & \multicolumn{2}{|c|}{... Saline } & \multicolumn{2}{|c|}{$\begin{array}{l}\text { Cortisone } \\
\text { acetate }\end{array}$} & \multicolumn{2}{|c|}{ Saline } & \multicolumn{2}{|c|}{$\begin{array}{c}\text { Cortisone } \\
\text { acetate }\end{array}$} \\
\hline & Mean & SE & Mean & SE & Mean & SE & Mean & SE \\
\hline & & & & Liver & & & & \\
\hline ○ & $18 \cdot 0$ & $I \cdot 5$ & - & - & $57 \cdot 3$ & $5 \cdot 4$ & - & - \\
\hline 2 & $18 \cdot 3$ & $I \cdot O$ & I 5.2 & $0.4^{*}$ & $62 \cdot 9$ & $2 \cdot 2$ & $70 \cdot 7$ & $2 \cdot 4^{*}$ \\
\hline 10 & $20 \cdot 3$ & 0.7 & $25 \cdot 4$ & $I \cdot 3 * *$ & $75 \cdot 7$ & $6 \cdot 1$ & $130 \cdot 9$ & $12 \cdot 8 * *$ \\
\hline & & & & Muscl & & & & \\
\hline$\circ$ & $20 \cdot 6$ & 0.9 & - & - & $9 \cdot 50$ & 0.79 & - & - \\
\hline 2 & 19.5 & 0.7 & $20 \cdot 6$ & $\mathrm{I} \cdot 5$ & $8 \cdot 42$ & 0.23 & $8 \cdot 82$ & 0.80 \\
\hline Io & $17 \cdot 3$ & $I \cdot I$ & $15 \% 4$ & I. 6 & $8 \cdot 20$ & 0.67 & 4.98 & $0.53^{*}$ \\
\hline
\end{tabular}

Differences between saline- and cortisone acetate-treated animals were significant by Student's $t$ test: ${ }^{*} P<0.05,{ }^{* *} P<0.01$.

+ For details, see Lunn, Whitehead \& Baker (1976).

Liver weight. Although there was a decrease in body-weight and muscle weight of the animals receiving cortisone acetate, the weight of the liver had increased dramatically only $24 \mathrm{~h}$ after the first injection (Fig. I $c$ ), reaching a peak by day 4 . The weight of the liver, expressed as a percentage of body-weight continued to increase until day 7 , after which it slowly decreased.

\section{Tissue protein contents}

Liver. Values for liver protein concentrations and total liver protein are given in Table 2, together with corresponding values for gastrocnemius muscle. On day 2, liver protein concentration ( $\mathrm{mg} / \mathrm{g}$ wet weight) in the cortisone acetate-treated animals was lower than in the saline-injected group, but as there had been an increase in the over-all size of the liver, the total protein content of the liver had increased. By day ro both the concentration of protein and the total protein content were significantly higher in the cortisone acetate-treated animals.

Muscle. In contrast, by day to total gastrocnemius protein content had been significantly reduced by cortisone acetate treatment and protein concentration in the muscle was lower as well, although not significantly so.

Plasma. Fig. 2 shows the changes in plasma albumin concentrations occurring during the experiment. After $6 \mathrm{~d}$ on the low-protein diet (day o), mean plasma albumin had decreased significantly to $25.7 \mathrm{~g} / 1$, compared with the initial value of $31 \cdot 7 \mathrm{~g} / \mathrm{l}$. On day $\mathrm{r}, 24 \mathrm{~h}$ after the first injection of cortisone acetate, there was a significant increase in albumin concentration. The increase continued and reached a maximum value of $47 \cdot 2 \mathrm{~g} / \mathrm{l}$ by day 7 , after which concentrations tended to decrease again. 


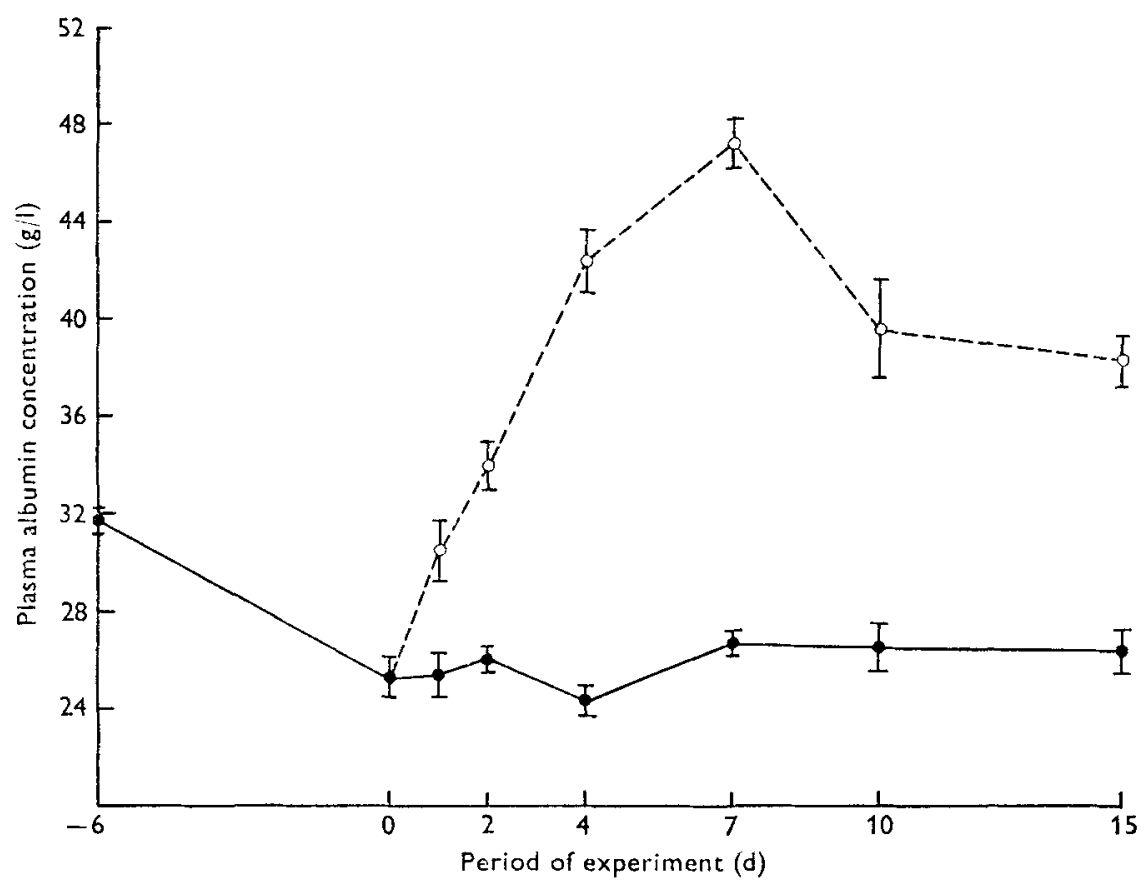

Fig. 2. Change in plasma albumin concentration (g/l) induced by daily subcutaneous injections of $1.25 \mathrm{mg}$ cortisone acetate to rats fed on a low-protein diet ( $31 \mathrm{~g}$ protein $/ \mathrm{kg}$ ) (for details of diet, see Lunn, Whitehead \& Baker (I976)). Mean values with their standard errors, represented by vertical bars, for five rats/group, except day 6 before the start of injections and day 0 , when injections were started, when there were ten rats/group. ( $->)$, Saline (9 g sodium chloride/1)injected; $(\mathrm{O}--\mathrm{O})$, cortisone-injected. The increase in plasma albumin was significant at all intervals, before and after the start of injections.

There was a similar increase in total plasma protein concentration in the cortisone acetate-injected animals, from (mean $\pm \mathrm{sE} ; \mathrm{g} / \mathrm{l}$ ) $45^{\cdot 1} \pm 0 \cdot 4$ to $66 \cdot 9 \pm \mathrm{r} \cdot 3$ on day 7 . The globulin component was, however, not significantly affected, (mean $\pm \mathrm{SE} ; \mathrm{g} / \mathrm{l}) \mathrm{r} 8 \cdot 5 \pm$ 0.9 v. $19.7 \pm \mathrm{I} \cdot 0$, indicating it was unlikely that the changes found in albumin concentration were secondary to changes in plasma volume.

\section{Plasma hormone concentrations}

Plasma corticosteroid concentrations are given in Table 3 . Values given for salineinjected animals are those for corticosterone alone, but in injected animals they represent cortisone plus corticosterone. Although there was some variation in the level of corticosterone in the saline-injected animals, perhaps due to the stress of injection, cortisone administration increased the total circulating corticosteroid concentration about sevenfold.

Plasma insulin concentrations also increased after administration of cortisone acetate. Values which eventually reached about five to six times the plasma insulin concentrations for saline-injected animals are also given in Table 3 . 


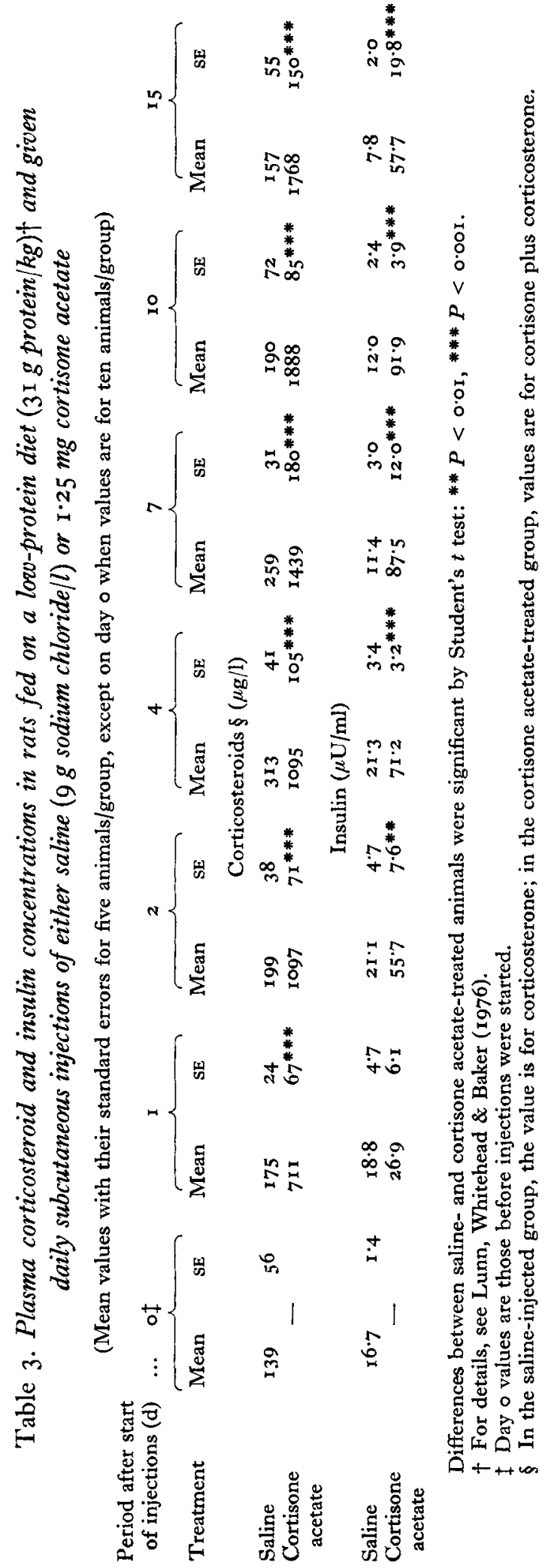




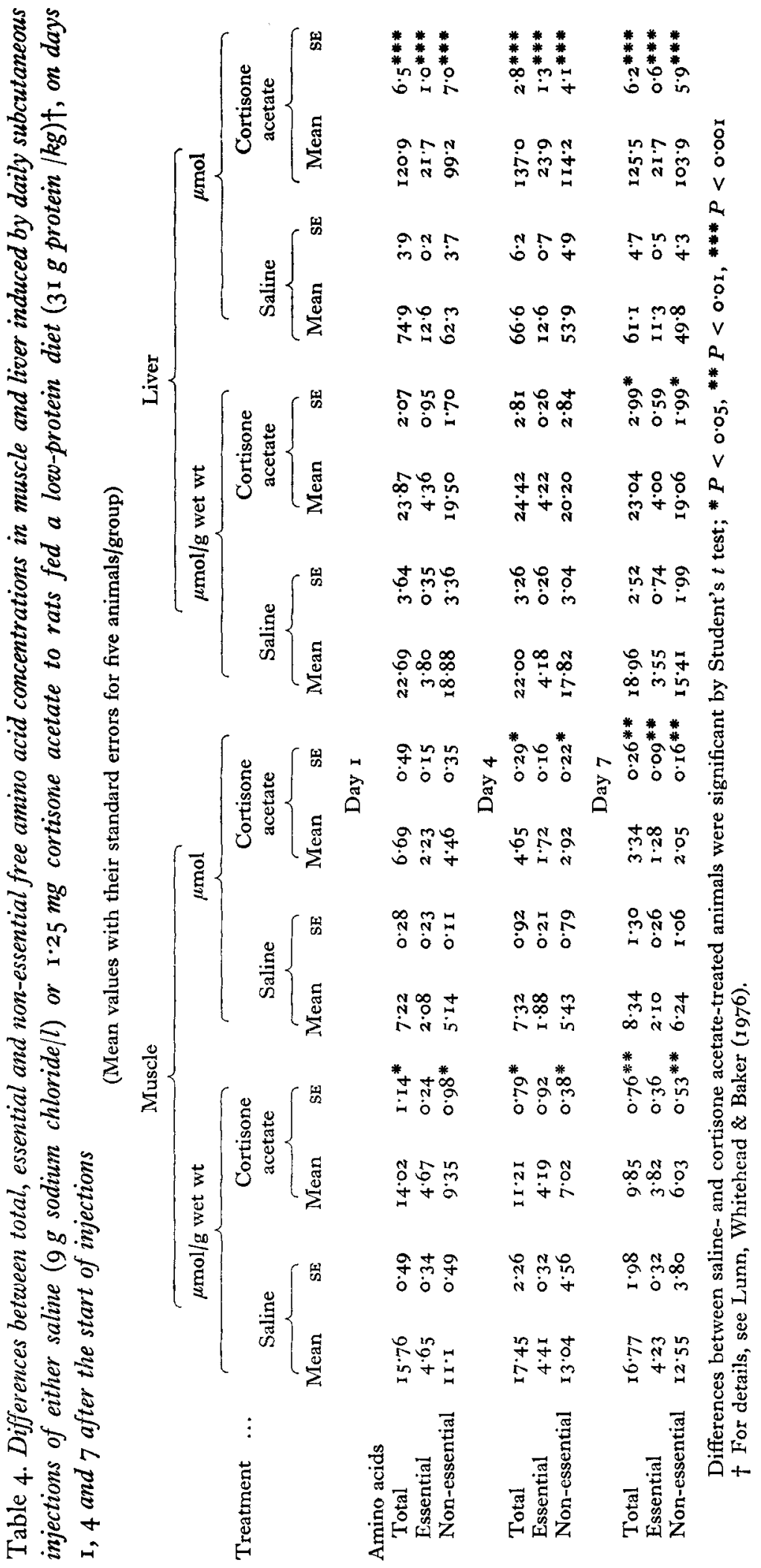


Table 5. Differences between total, essential and non-essential amino acid concentrations (mmolll) in plasma induced by daily subcutaneous injections of either saline $(9 \mathrm{~g}$ sodium chloride $/ \mathrm{l}$ ) of $\mathrm{x} \cdot 25 \mathrm{mg}$ cortisone acetate to rats fed on a low-protein diet (3 $\mathrm{I} g$ protein $/ \mathrm{kg}$ ) †, on days 1,4 and 7 after the start of injections

(Mean values with their standard errors for five animals/group)

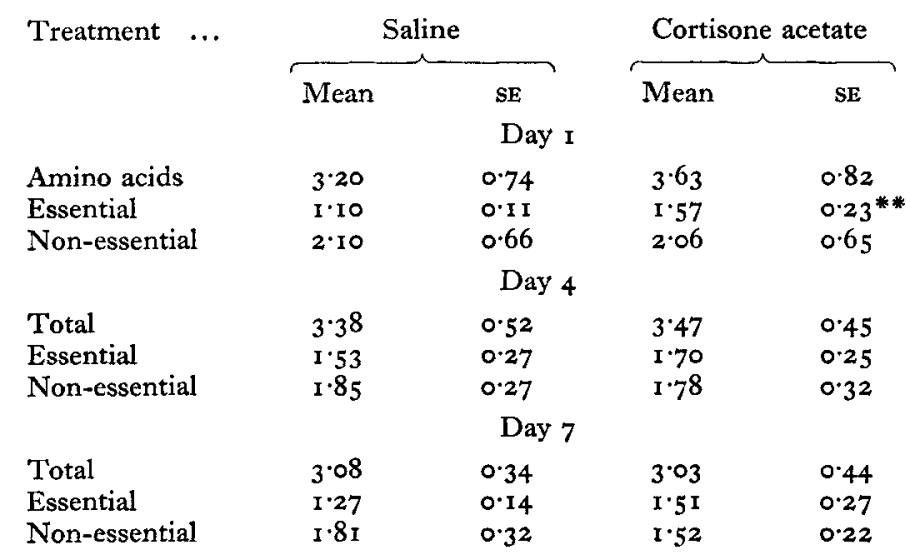

Differences between saline- and cortisone acetate-treated animals were significant by Student's $t$ test: * $P<0.01$.

$\dagger$ For details, see Lunn, Whitehead \& Baker (1976).

\section{Tissue free amino acids}

The concentrations of seventeen amino acids were determined in plasma, liver and muscle $\mathrm{I}, 4$ and $7 \mathrm{~d}$ after the daily injections of cortisone acetate or saline had started.

\section{Total free amino acid concentrations}

Total, total essential and total non-essential amino acids have been calculated from the values for individual amino acids and results, expressed as $\mu \mathrm{mol} / \mathrm{g}$ wet weight for liver and muscle, and $\mu \mathrm{mol} / 1$ for plasma, and also as $\mu \mathrm{mol}$ for liver and muscle, are given in Tables 4 and 5 .

The most dramatic changes in response to cortisone acetate occurred in the muscle (Table 4). From day I onwards the concentrations of total and non-essential amino acids became progressively decreased, the reduction in the non-essential amino acids reaching $50 \%$ by day 7 . There was a small decrease only in the concentration of essential amino acids, which was never significantly different from values for the saline-injected group. When expressed on a whole organ basis, however, values for all three groups of amino acids were markedly reduced; this reduction was significant by day 7 .

Liver total amino acid concentration (Table 4), on the other hand, was higher in the cortisone acetate-treated animals than in the saline-injected group, but this was contributed to by a decrease in concentration with age in the latter animals. Differences were evident on day I, but only reached significance by day 7 . Essential and nonessential amino acid levels were both maintained at higher concentrations in the cortisone acetate-treated group, but only with the non-essential amino acids was the 
:

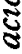

총

\&

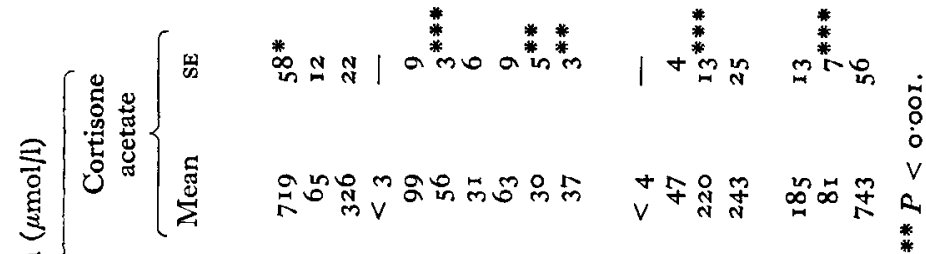

รี

ป

:

8 \&

ริ

要 1

ड़ डे

క 5

กิ

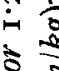

농

ह

क

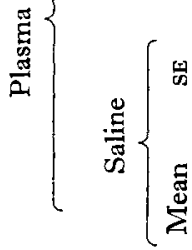

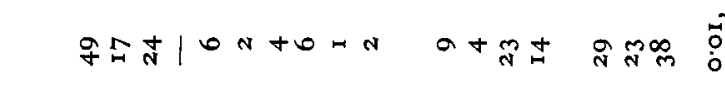

$\frac{8}{3}$

$\therefore$.

a $\sqrt{0}$

ह

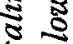

ذ)

bे

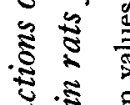

. लू

范

है

总

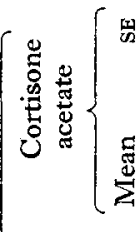

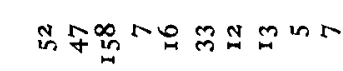

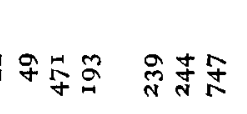

总

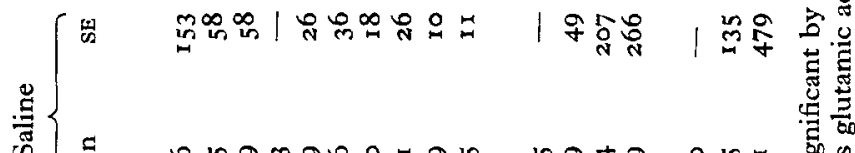

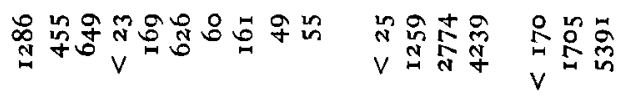

记

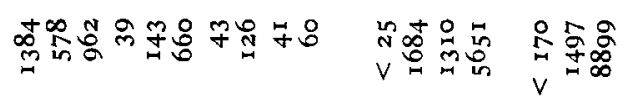

है

ते एँ

苛

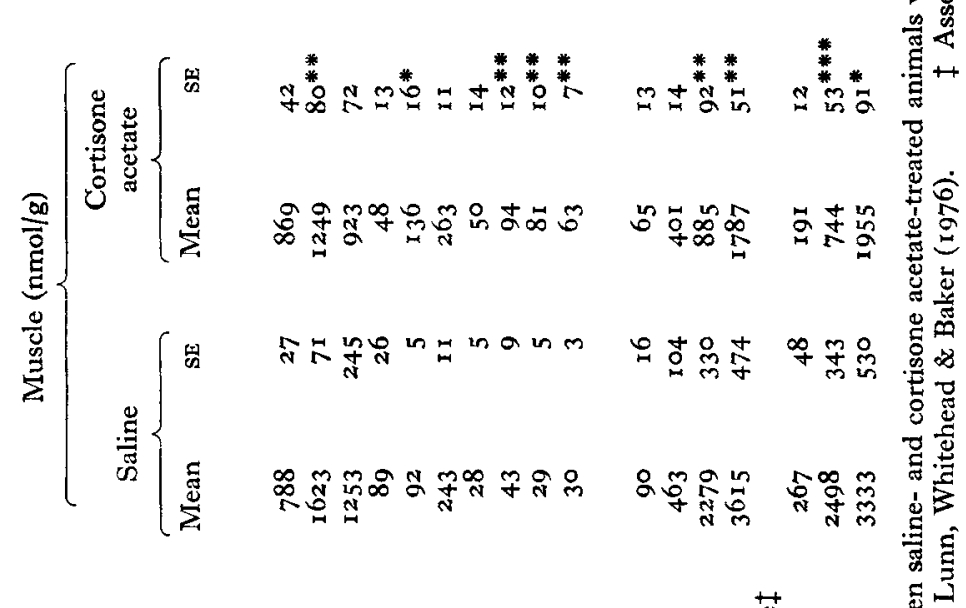

D

ษั .

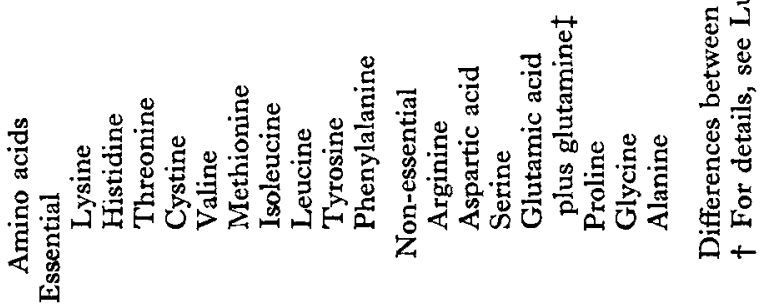


difference significant (day 7). Expressing these differences on a whole organ basis, however, revealed a large increase in the free amino acid content, both essential and non-essential, of liver from day I onwards.

In the plasma there also tended to be in increase in essential amino acid concentration, but only on day I was this significant (Table 5). There was no significant difference either in total or non-essential amino acid concentrations between the two groups of animals.

\section{Individual free amino acid concentrations}

Amino acid concentrations on day 7 typified the response of the animals to cortisone acetate injection, and therefore only these values are given in Table 6.

Muscle. Concentrations of all non-essential amino acids were reduced in response to cortisone acetate, and the difference was significant for serine, glutamic acid plus glutamine, glycine and alanine. The response of the essential amino acids was mixed: histidine concentration decreased significantly in cortisone acetate-treated animals compared with the saline-injected controls, but valine, leucine, tyrosine and phenylalanine were all increased in concentration.

Liver. Differences in individual essential amino acid concentrations in the liver were much less marked than those in the muscle. Threonine, and to a lesser extent lysine and histidine, were higher in concentration with cortisone acetate treatment, but these differences were not significant. With the non-essential amino acids, a large decrease in serine concentration occurred, but aspartic acid, glutamic acid plus glutamine and alanine all increased significantly.

Plasma. The plasma concentrations of all essential amino acids except histidine were increased by cortisone acetate administration, but only with lysine, methionine, tyrosine and phenylalanine was the difference significant. As in muscle and liver, the serine concentration in plasma was greatly reduced, as was glycine. Arginine concentration decreased to values which were not detectable and proline concentration decreased also, but not significantly; there was little change with other amino acids.

\section{DISCUSSION}

The present work has confirmed the almost forgotten suggestion of Castellanos \& Arroyave (196r) that the features of malnutrition which develop in response to a low protein intake could be altered by the adjustment of plasma glucocorticoid concentrations. In I96I, however, marasmus and kwashiorkor were regarded as two separate diseases and their diet-mediated aetiology seemed clear-cut; the role of corticosteroids was considered of secondary importance. This view probably was inaccurate and it now seems possible that the hormonal pattern on to which the protein deficiency is superimposed decides the ultimate clinical features of the disease.

In this study, rats fed on a low-protein, high-carbohydrate diet for $6 \mathrm{~d}$ developed features which are regarded as early signs of the type of protein-energy malnutrition which leads to kwashiorkor. Plasma albumin concentrations during this period decreased by $6 \mathrm{~g} / \mathrm{l}$, a typical distorted plasma amino acid pattern developed and, although 
the growth of the animals ceased, there was no actual loss of weight. Such plasma protein changes and associated alterations in amino acid patterns in plasma, liver and muscle have been described in detail elsewhere (Lunn et al. 1976).

Daily injections of cortisone acetate caused a significant reversal of many of these changes. Although dietary intake was unaffected, there was an immediate increase in plasma albumin concentration and liver weight and its protein content increased dramatically as well. At the same time, there was a loss in muscle weight and also a reduction in muscle protein concentration. These features are typical of changes which in the child would eventually lead to marasmus.

The diagnostic feature distinguishing kwashiorkor from marasmus is the presence or absence of oedema (Lancet, I970). Hypoproteinaemia, caused in nutritional conditions mainly by severe hypoalbuminaemia, reduces the colloidal osmotic pressure of the blood and this is closely related to the development of oedema (Coward, I975). An increase in albumin concentration in response to cortisone would make it unlikely that any subsequent severe malnutrition would be associated with oedema.

The main question must be how relevant are these rat studies to the development of protein-energy malnutrition in children? The magnitude of the increase in blood concentrations of glucocorticoids reproduced in this experiment (sevenfold) was adjusted to mirror that which has been found in severely wasted children in The Gambia (Lunn, Whitehead, Baker \& Austin, unpublished results). High plasma albumin concentrations, which developed in the rats, were found also in wasting rural Gambian children with increased plasma cortisol concentrations. This contrasts with what has been reported from Uganda, where kwashiorkor rather than marasmus predominates. Here rural children maintained normal cortisol concentrations, unless they were infected, until the onset of the acute phase of the disease (Lunn et al. 1973). These children had much lower plasma albumin concentrations than their counterparts in The Gambia.

A shortcoming of this study, however, was the concomitant increase in plasma insulin concentration as well as that of corticosteroid. (In The Gambia, insulin concentrations remain low during the development of marasmus, indeed they decreased as cortisol concentration increased.) The increased insulin concentrations must have limited the catabolic effects of the cortisone acetate. Another anomaly was the increased size of the liver in the cortisone acetate-treated animals: this does not occur in wasted children. A reason for this difference between the human and animal situation could be that, in the former, high cortisol concentrations are usually associated with reduced food intakes arising, for example, because of illness or a shortage of food. In this study food intake was the same in both groups of animals. It is unlikely that the increase in liver protein was a response to insulin, since Hanoune \& Chambaut (1972) have reported that cortisone-induced liver protein synthesis can still occur in alloxan-diabetic rats.

With such gross alterations in the redistribution of protein brought about by cortisone acetate, one would have anticipated a similar response in plasma and tissue free amino acid concentrations and pool size. The administration of cortisone to wellnourished animals has been found to produce a rapid increase in plasma, liver and 
muscle amino acid concentrations (Kaplan \& Shimizu, I962; 1963; Ryan \& Carver, 1963; Betheil, Feigelson \& Feigelson, 1965; Weber, Srivastava \& Singhal, 1965), although these increases only lasted for about $24 \mathrm{~h}$ after the first glucocorticoid injection. After this period concentrations of most essential amino acids were decreased below normal values in all tissues (Ryan \& Carver, 1963 ; Munro, 1970). In the present experimental design, where there was already a distorted amino acid pattern in plasma, liver and muscle in response to the low-protein diet, some normalization of these patterns might have been expected.

Plasma amino acid concentration was found to have the anticipated trend: essential amino acids increased, and the non-essential amino acids decreased. The amino acid ratio, essential: non-essential increased from 0.69 to $\mathrm{I} \cdot 00$; the mean value in rats fed on a diet containing $200 \mathrm{~g}$ protein $/ \mathrm{kg}$ is $\mathrm{I} \cdot 15$.

In the muscle, which before cortisone acetate administration had received a preferential share of the dietary amino acids (Lunn et al. 1976), there was a decrease in the concentrations of both total and non-essential amino acids, and after taking account of the reduced muscle size there was also a significant reduction in the essential amino acid content. In contrast, in the liver, which on a low-protein diet had been relatively deprived of amino acids, there was a significant increase in the over-all free amino acid pool.

Although the distribution of amino acids among the three tissues did therefore respond somewhat as predicted, there were nevertheless certain anomalies. For example, liver and plasma valine concentrations were not corrected to any significant extent; furthermore, all the essential amino acids were still much lower in concentration than those previously reported in the liver and plasma of well-fed control animals (Lunn et al. 1976). This was perhaps surprising in view of the increased liver protein and plasma albumin synthesis which was occurring.

The explanation is probably associated with the other metabolic effects of glucocorticoids. It is well known that corticosteroids stimulate the production of a number of amino acid transaminating and catabolizing enzymes (Rosen, Harding, Milholland $\&$ Nicol, 1963 ; Kenney, 1970). Presumably, therefore, amino acids not used for protein synthesis in the liver would be catabolized at a rate higher than normal. The considerably increased concentrations of alanine, glutamate and aspartate seen in the liver would be in keeping with this hypothesis; all are involved in transamination reactions.

The mechanism of the glucocorticoid stimulation of liver protein synthesis is not understood; this has been discussed by Munro (1970). He concluded that an increased availability of amino acids from tissue catabolism is unlikely to be a major cause, as thyroxine, like glucocorticoids, produces a hyperaminoacidaemia, but unlike corticosteroids, does not stimulate liver protein synthesis.

Albumin synthesis is generally regarded as being sensitive to the concentration of essential amino acids in the plasma (Kirsch, Saunders, Frith, Wicht, Kelman \& Brock, 1969; Waterlow \& Alleyne, 1971). In this experiment, however, a very large increase in plasma albumin concentration occurred, presumably caused by an increased synthetic rate, without a major improvement in plasma essential amino acid concentrations. What did change, however, was the pattern of amino acids, in particular the 
amino acid ratio, essential: non-essential, and it may be that it is the pattern of amino acids rather than their absolute concentrations which are crucial to albumin synthesis. Alternatively, merely the increased size of the liver and consequent greater synthesizing facility may have accounted for the increase in plasma albumin.

\section{REFERENCES}

Abbassy, A. S., Mikhail, M., Zeitoun, M. M. \& Ragab, M. (1967). F. trop. Pediat, x3, 54.

Alleyne, G. A. O. \& Young, V. H. (1967). Clin. Sci. 33, 189.

Betheil, J. J., Feigelson, M. \& Feigelson, P. (1965). Biochim. biophys. Acta 104, 92.

Castellanos, H. \& Arroyave, G. (I96r). Am. F. clin. Nutr. 9, 186.

Coward, W. A. (1975). Br. F. Nutr. 34, 459 .

Gornall, A. G., Bardawill, E. S. \& David, M. M. (1949). J. biol. Chem. 177, 75 1.

Hales, C. N. \& Randle, P. J. (1963). Biochem. Y. 88, i 37.

Hanoune, J. \& Chambaut, A. M. (1972). Horm. Metab. Res. 4, 254.

Kaplan, S. A. \& Shimizu, C. N. S. (1962). Am. F. Physiol. 202, 659.

Kaplan, S. A. \& Shimizu, C. N. S. (1963). Endocrinology 72, 267.

Kenney, F. T. (1970). In Mammalian Protein Metabolism, vol. 4, p. 13 [ [H. N. Munro, editor]. New York and London: Academic Press.

Kirsch, R. E., Saunders, S. J., Frith, L., Wicht, S., Kelman, L. \& Brock, J. F. (1969). Am. F. clin. Nutr. 22, I 559 .

Lancet (1970). Lancet ii, 302 .

Lunn, P. G., Whitehead, R. G., Hay, R. W. \& Baker, B. A. (I973). Br. F. Nutr. 29, 399.

Lunn, P. G., Whitehead, R. G. \& Baker, B. A. (1976). Br. F. Nutr. 36, 219.

Munro, H. N. (editor) (1970). In Mammalian Protein Metabolism, vol. 4, p. 299 [H. N. Munro, editor]. New York and London: Academic Press.

Murphey, B. E. P. (1967). F. clin. Endocr. Metab. 27, 973.

Northam, B. E. \& Widdowson, G. W. (1967). Ass. Clin. Biochem. tech. Bull. no. 11.

Rao, K. S. J. (1974). Lancet i, 709.

Rao, K. S. J., Srikantia, S. G. \& Gopalan, C. (1968). Archs Dis. Childh. 43, 365.

Rosen, F., Harding, H. R., Milholland. R. J. \& Nicol, C. A. (1963). 7. biol. Chem. 238, 3725.

Ryan, W. L. \& Carver, M. J. (1963). Proc. Soc. exp. Biol. Med. I14, 816.

Technicon Instruments Co. Ltd (1967). Technicon Clinical Method no. 519-73 E. Basingstoke, Hants: Technicon Instruments Co Ltd.

Waterlow, J. C. \& Alleyne, G. A. O. (1971). In Advances in Protein Chemistry, vol. 25, p. II7 [C. B. Anfinsen, J. T. Edsell and F. M. Richards, editors]. New York and London: Academic Press.

Weber, G., Srivastava, S. K. \& Singhal, R. L. (1965). \%. biol. Chem. 240, 750.

Whitehead, R. G. \& Alleyne, G. A. O. (1972). Br. med. Bull. 28, 72. 